\title{
THE RESEARCH RESULTS OF MATHEMATICS MODEL INFLUENCE TO ADVANCE THE EFFICIENCY OF ELECTRONICS BRANCH IN VOCATIONAL EDUCATION
}

\author{
Július ARPÁS̆ - Vladimír SOTÁK - Anna TIRPÁKOVÁ
}

\begin{abstract}
Here are published the results of research which js focused to use the mathematic model in proffesional education at vocational school in this paper. Using the latest technology based on computer projection of electronical circuits it is the way to advance the level of our vocational education. The paper contains the results of two years of pedagogical experiment for higher efficiency of education by e-learning is presented here.
\end{abstract}

Key words: E-learning, mathematic model of education, higher efficiency of education, pedagogical research, ICT and education.

\section{VÝSLEDKY VÝSKUMU VPLYVU MATEMATICKÉHO MODELOVANIA NA ZVÝŠENIE EFEKTIVITY VÝUČBY PREDMETU ELEKTRONIKA NA SOŠ}

\begin{abstract}
Abstrakt: Autori vo svojom príspevku interpretujú výsledky výskumu orientovaného na pôsobenie matematického počitačového modelovania vo výučbe. Zaradením najmodernejších technológií založených na počítačovom návrhu elektronických obvodov by sa mala zvýšit' atraktivita elektrotechnického odboru avneposlednom rade aj kompatibilita stredoškolského odborného vzdelávania na Slovensku s vyspelými krajinami spoločného európskeho priestoru. Príspevok je určený na oboznámenie odbornej verejnosti s výsledkami dvojročného pedagogického experimentu, ktorý sa uskutočnil s cielom zvýšit' efektivitu tradičného vzdelávania na SŠ prostredníctvom e- learningu.
\end{abstract}

Kl'účové slová: E -learning, matematické modelovanie vo výučbe, zvýšenie efektivity vyučovania, pedagogický výskum, IKT a vzdelávanie.

\section{1 Úvod}

Ak by sme posudzovali odborné predmety z hl'adiska obsahu na strednej škole s elektrotechnickým zameraním potom premet elektronika patrí medzi profilový predmet s viacerými zameraniami. Obsahom predmetu sú $\mathrm{v}$ druhom ročníku štúdia stavebné prvky elektronických obvodov. Nevýhodou stavebných prvkov (súčiastok) elektronických zariadení v porovnaní so stavebnými prvkami mechanických zariadení je skutočnost', že jednoduchá manuálna manipulácia s nimi, prípadne vizuálny kontakt neumožňuje zistit' príčiny ich zlyhania. Tá vyžaduje dôkladnú analýzu elektrických vlastností jednotlivých súčiastok tvoriacich obvod, podl'a určitého algoritmu za pomoci merania elektrických veličín. Výsledky meraní sa musia priradit' fyzikálnym vlastnostiam jednotlivých stavebných prvkov a d'alšími vyššími rozumovými operáciami ako je aplikácia, syntéza je možné diagnostikovat' príčiny. Aby bolo možné používat' vyššie rozumové operácie je nevyhnutné, aby žiaci ovládali základné učivo. Základné učivo predmetu vyžaduje dôkladné zapamätanie fyzikálnych princípov ako aj výsledné grafické tvary (znovu - spoznanie) Volt -ampérových charakteristík jednotlivých stavebných prvkov.

Najnižšiu úroveň vedomostí ako je zapamätanie, znovu - spoznanie je možné získat' pri tradičnom spôsobe vzdelávania iba memorovaním, ktoré najmä žiaci s priemernými predpokladmi pre štúdium úplne ignorujú. Nosiče elektrického náboja vol'ným okom vidiet' nie je a preto je obsah učiva pre nich abstraktný. Menej zdatní žiaci väčšinou už na začiatku školského roka rezignujú. Potom sa stáva pravidlom, že učitelia v príbuzných predmetoch pri vertikálnom rozširovaní učiva vo vyššom ročníku znovu preberajú učivo druhého ročníka, aby žiaci vôbec porozumeli nadstavbovému učivu. Oneskorenie, ktoré týmto spôsobom vznikne negatívne pôsobí na rozsah preberaného učiva v príbuzných a nadväzujúcich predmetoch. Vplyvom nevyhnutného prispôsobovania sa učitel'a menej zdatným žiakom, talentovani žiaci nemôžu napredovat' a stanú sa z nich pre nekonečné opakovanie už dávno zvládnutého učiva priemerní žiaci. Podl'a nášho názoru, riešením je zvýšenie motivácie žiakov objasňovaním významu obsahu učiva 
v konkrétnych praktických aplikáciách (aj s horizontálnym zosúladením obsahu predmetu Prax) a cielené zaradenie vyučovacích hodín na počítačovom simulačnom programe.

\section{POČÍTAČOVÉ MODELOVANIE PROSTREDNÍCTVOM SIMULAČNÉHO PROGRAMU MICROCAP}

Dôvodom zaradenia práve simulačného programu Microcap bola jej bezplatná dostupnost' vo forme demoverzie a aj skutočnost', že demoverzia poskytuje plne funkčný program s obmedzením len na počet elektronických prvkov dostupných v knižnici programu, ktorý je pre účely stredoškolského štúdia nepodstatný. Podrobnejší prehl'ad dostupných simulačných programov určených pre elektroniku poskytuje publikácia R. Láníčka (Láníček, 2002). Naše skúsenosti s používaním simulačného programu Microcap sme spracovali $\mathrm{v}$ našich príspevkoch (Arpáš, 2007), (Arpáš 2008).

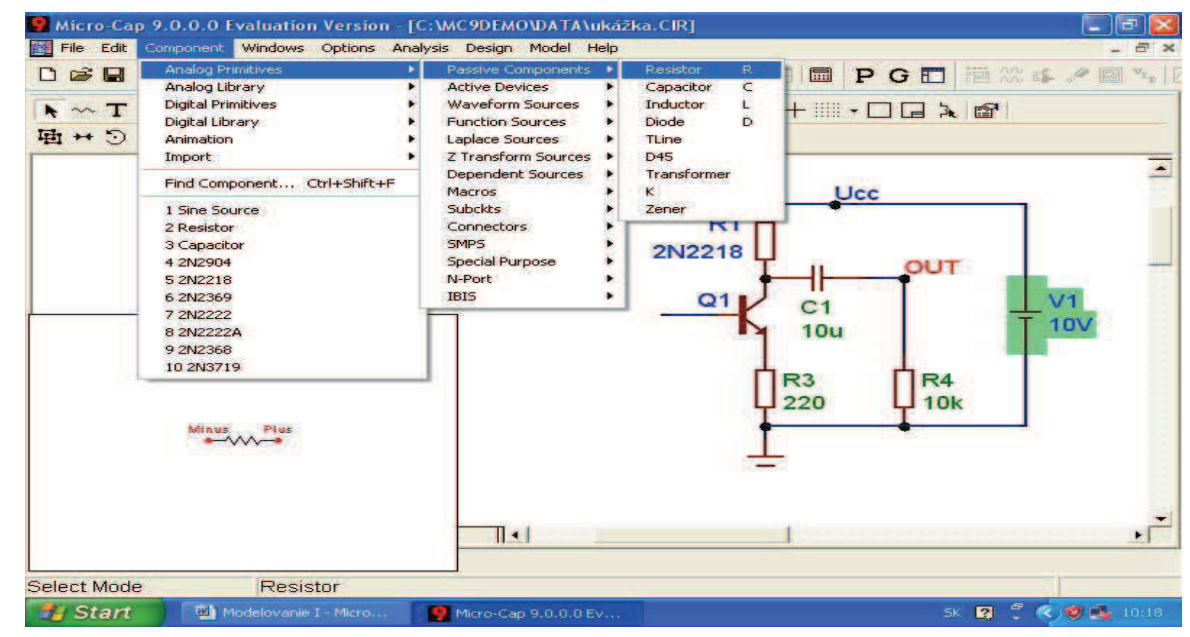

Obr. č. 1: Základné prostredie programu Microcap verzie 9.

Výučba vyžaduje dataprojektor a miestnost' s výpočtovou technikou, v ktorej má každý žiak skupiny počítač s nainštalovaným programom MicroCap s verziou 7 a vyššou.

\section{Výskumná čast'}

Výskumná čast' je zameraná na transparentné získanie výsledkov $\mathrm{z}$ experimentálneho pedagogického výskumu, jeho štatistické vyhodnotenie a interpretáciu získaných poznatkov týmto výskumom. Pri organizácii pedagogického výskumu sme sa riadili doporučeniami I. Tureka (Turek, 1996)

\section{Ciele výskumu}

Hlavným cielom nášho výskumu bolo vyhodnotit' vplyv informačných a komunikačných technológií na zvýšenie efektívnosti výučby vybraného technického predmetu Elektronika na strednej odbornej škole.

Pri analýze vplyvu IKT na výučbu odborného predmetu sme sa zamerali na nasledujúce čiastkové ciele:

- Zistit' vplyv matematického modelovania v podobe simulačného programu na efektivitu získavania vedomostí žiakov zaradených do experimentu $\mathrm{v}$ predmete Elektronika $v$ druhom ročníku SPŠ v porovnaní so žiakmi vyučovanými tradične.

- Zistit' vplyv matematického modelovania v podobe simulačného programu na trvácnost' vedomostí žiakov $\mathrm{V}$ predmete Elektronika v druhom ročníku SPŠ zaradených do pedagogického experimentu v porovnaní so žiakmi vyučovanými tradične.

\section{Hypotézy výskumu}

Pre splnenie stanovených ciel'ov sme navrhli overenie hlavnej hypotézy:

Žiaci využivajúci matematické modelovanie vo forme simulačného programu implementovaného do výučby odborných predmetov budú lepšie motivovaní pri štúdiu daných predmetov, čím dosiahnu pozitívnejšie výsledky pri hodnotení ako žiaci kontrolnej triedy vyučovaní tradične.

\section{Pracovné hypotézy sú:}

H(1): Žiaci začlenení do programu vyučovacích hodín so zaradeným simulačným programom dosiahnu vyššie skóre $\mathrm{v}$ hodnotení $\mathrm{z}$ predmetu počas školského roka $\mathrm{v}$ porovnaní so žiakmi vyučovanými tradične/didaktické testy/ 
H(2): Žiaci začlenení do programu vyučovacích hodín so zaradeným simulačným programom budú mat' trvácnejšie vedomosti z predmetu ako žiaci vyučovaní tradične/didaktický test/

\section{Vzorka výskumu}

Predmetom realizovaného výskumu boli dosiahnuté vedomosti žiakov v predmete elektronika vyučovaného v 2. ročníku Strednej priemyselnej školy v Nitre s elektrotechnickým zameraním. Výberový súbor tvorili triedy menovanej školy počas dvoch školských rokov nasledovne:

- Pracovné hypotézy $\mathrm{H}(1), \mathrm{H}(2)$ boli v rámci pedagogického výskumu sledované u žiakov 2. ročníka V školských rokoch 2006/2007 a 2007/2008 na 117 respondentoch -žiakoch školy.

Pedagogický výskum sme prevádzali počas dvoch školských rokov z dôvodu nízkeho počtu vyčlenených vyučovacích hodín z osnov daného predmetu na realizáciu pedagogického výskumu. Ten bol podmienený s ciel'om nenarušit' pôvodnú štruktúru platných osnov navrhnutých Ministerstvom školstva Slovenskej republiky (d’alej MŠ SR), ktoré boli v tom čase záväzné pre všetky stredné školy.

Pre realizáciu plánovaného výskumu sme vybrali dostupnú vzorku žiakov na škole (dve triedy). Výberový súbor žiakov zaradených do ped. experimentu uvádzame $\mathrm{v}$ tabul'ke 1 .

\begin{tabular}{|c|c|c|c|}
\hline $\begin{array}{c}\text { Trieda s tradičným spô- } \\
\text { sobom vyučovania } \\
\text { (školský rok) }\end{array}$ & $\begin{array}{c}\text { Počet } \\
\text { žiakov }\end{array}$ & $\begin{array}{c}\text { Trieda s vyučovaním } \\
\text { rozšíreným o Microcap } \\
\text { (školský rok) }\end{array}$ & $\begin{array}{c}\text { Počet } \\
\text { žiakov }\end{array}$ \\
\hline 2. B (B1) v 2006/2007 & 29 & 2. A (A1) v 2006/2007 & 26 \\
\hline 2. A (A2) v 2007/2008 & 32 & 2. B (B2) v 2007/2008 & 30 \\
\hline
\end{tabular}

Tabul'ka 1: Počet respondentov dotazníka a vedomostných testov pedagog. experimentu.

\section{Metodika výskumu}

$\mathrm{Na}$ overenie platnosti hlavnej hypotézy a z nej vyplývajúcich pracovných hypotéz sme zvolili nasledovnú metodiku:

- na začiatku pedagogického experimentu sme vybrali dostupnú vzorku žiakov a realizovali vstupné testy (pretesty)

- na základe výsledkov vstupných testov sme určili experimentálnu a referenčnú triedu

- v experimentálnych triedach prebiehalo vyučovanie rozšírené o zaradený simulačný program Microcap a v referenčných triedach tradičným spôsobom

- po ukončení každej experimentálnej dvojhodinovky sa všetci žiaci (experimentálnej aj kontrolnej triedy) zúčastňovali priebežných testov

- na konci pedagogického experimentu sa realizoval výstupný test (posttest)

Ako prostriedok merania úrovne osvojených vedomostí sme zvolili didaktické testy. Použité didaktické testy boli vlastnej konštrukcie v ktorých sme rešpektovali časovú dotáciu v súlade s osnovami pod č. 2751/03-43 schválenými dňa 17. 4. 2003 MŠ SR a tematické celky $\mathrm{s}$ vyššou dotáciou hodín mali $\mathrm{v}$ teste zastúpený väčší počet otázok. Konštrukcia použitých didaktických testov bola konzultovaná s učitel'mi odborných elektrotechnických predmetov a jednotlivé úlohy testov boli schválené predmetovou komisiou na škole, na ktorej bol pedagogický experiment realizovaný. Všetci žiaci zúčastnení vo výskume riešili ten istý didaktický test.

Vstupné testy pozostávali zo základných vedomostí z predmetu vyučovaných $\mathrm{v}$ triedach tradičným spôsobom $\mathrm{v}$ prvých dvoch mesiacoch štúdia. Až po uplynutí tohto obdobia boli na základe výsledkov pretestu rozdelené triedy na experimentálnu a kontrolnú. V experimentálnej sme na subjekty experimentu pôsobili nezávislou premennou - Microcapom. V kontrolnej triede vyučovanie prebiehalo štandardným spôsobom bez použitia simulačného programu. Priebežné testy boli zamerané na overovanie vedomostí žiakov získaných počas prebiehajúceho pedagogického experimentu. Výstupný test bol zostavený metódou selekcie z otázok priebežných testov.

Na získanie údajov potrebných pre overenie platnosti stanovených hypotéz sme zvolili nasledovné metódy:

- Prirodzený pedagogický experiment - hlavná metóda výskumu,

- didaktické testy - na overenie hypotéz H(1), $\mathrm{H}(2)$,

- štatistické metódy na spracovanie výsledkov výskumu. 


\section{Pedagogický experiment}

Pre experiment sme vybrali dve triedy strednej priemyselnej školy Ul. Fraňa Král'a v Nitre s elektrotechnickým zameraním počas dvoch školských rokov 2006/2007 a 2007/2008. Vzhl'adom $\mathrm{k}$ tomu, že úroveň vedomostí $\mathrm{v}$ oboch triedach nebola štatisticky významne rozdielna, experimentálnu skupinu tvorili triedy, ktoré dosiahli vyššiu strednú hodnotu a v prípade rovnosti väčší rozptyl okolo strednej hodnoty. Kontrolnú, tvorili triedy s vyššou strednou hodnotou vo vstupných testoch (tabul'ka 2). Pedagogický experiment prebiehal $\mathrm{v}$ rámci cvičení z predmetu. Žiaci jednotlivých tried boli rozdelení na devät' až desat' členné skupiny z dôvodu potreby učebne s výpočtovou technikou v ktorej každý žiak skupiny má svoj počítač.

\section{Didaktický test}

Za účelom výberu žiakov do experimentálnej a kontrolnej triedy a zist'ovania ich priebežnej vedomostnej úrovne počas pedagogického experimentu, ale aj trvalosti ich novozískaných vedomostí, sme zostavili tri druhy testov:

- Vstupné,

- priebežné,

- výstupný.

Pri zostavovaní didaktických testov sme sa riadili odporúčaniami I. Tureka (Turek, 1995). Štatistické vyhodnotenie didaktických testov sme overovali pomocou Cochranovho - Coxonovho testu, ktorý predstavuje jednu z podôb parametrických $\mathrm{t}$-testov pre nezávislé výbery (Tirpáková, 2007).

\section{Vstupné testy}

Aby sme zabezpečili rovnocennost' experimentálnej a kontrolnej triedy počas obidvoch rokov pedagogického výskumu, boli triedam A1, B1 a tiež A2, B2 vždy na začiatku školského roka zadané vstupné testy. Vstupné testy pozostávali zo štyroch didaktických testov z tematického celku Základy číslicovej techniky a boli skórované binárne (každej správnej odpovedi sme priradili 1 bod) pričom každej úlohe boli pridelené rôzne váhy významu. Pri vyhodnocovaní vstupných didaktických testov sme vyslovili nasledujúcu nulovú hypotézu $H_{0}$ : Skóre vstupných vedomostných testov oboch tried sa štatisticky významne nelíši.

Oproti testovanej nulovej hypotéze $H_{0}$ sme položili alternatívnu hypotézu $H_{1}$.

\section{$H_{1}$ : Dosiahnuté skóre vo vstupných didaktických testoch je $\mathrm{v}$ testovaných triedach štatisticky významne rozdielne.}

Platnost' nulovej hypotézy sme overovali pomocou Cochranov - Coxonovho testu a výsledné štatistické hodnoty sme zapísali do tabulky 2.

1. Vstupný test bol zameraný na výpočet uzlových napätí na predloženej schéme zapojenia lineárneho obvodu. Test obsahoval osem jednoduchých úloh s rôznou váhou významu. Trieda bola rozdelená do dvoch skupín, žiaci sedeli v laviciach po jednom za sebou, aby sa zabránilo opisovaniu.

Pre prvý vstupný test platí:

- $\quad$ v prvom roku výskumu pre triedy A1, B1, ked'že vypočítaná hodnota testovacej štatistiky $\mathrm{t}_{\text {stat }}=-1,886$, čo je menšia hodnota ako kritická tabul'ková hodnota (2,008), nulovú hypotézu $H_{0}$ nemôžeme zamietnut'. To znamená, že skóre prvého vstupného vedomostného testu medzi žiakmi oboch tried sa štatisticky významne nelíši.

- $\mathrm{v}$ druhom roku výskumu pre triedy A2, B2, ked'že $t_{\text {stat }}=0,435<2,001$ nulovú hypotézu $H_{0}$ nemôžeme zamietnut'. To znamená, že skóre prvého vstupného vedomostného testu sa štatisticky významne nelíši medzi žiakmi oboch tried.

2. Vstupný test zist'oval vedomosti $\mathrm{z}$ učiva zameraného na reálny napätový a prúdový zdroj. Obsahoval pät’ jednoduchých úloh skórovaných binárne s rôznymi váhami významu.

Pre druhý vstupný test platí:

- v prvom roku výskumu pre triedy $\mathrm{A} 1, \mathrm{~B} 1$, ked', že $t_{\text {stat }}=-1,102<2,008$ nulovú hypotézu $H_{0}$ nemôžeme zamietnut'. To znamená, že skóre druhého vstupného vedomostného testu sa štatisticky významne nelišsi medzi žiakmi oboch tried;

- v druhom roku výskumu pre triedy A2, B2, ked'že $t_{\text {stat }}=0,698<2,001$ nulovú hypotézu $H_{0}$ nemôžeme zamietnut'. Teda, skóre druhého vstupného vedomostného testu sa štatisticky významne nelišsi medzi žiakmi oboch tried. 
Interpretácia výsledkov zo vstupných testov.

Uplatnením štatistických metód sme vo všetkých štyroch vedomostných testoch nulovú hypotézu nemohli zamietnut'. To znamená, že skóre, dosiahnuté vo vedomostných testoch $\mathrm{u}$ žiakov $\mathrm{v}$ testovaných triedach 2 . A, 2. B sa vobidvoch rokoch pedagogického výskumu štatisticky významne nelíšili. Môžeme teda povedat', že na začiatku realizácie experimentu sme preverili kritérium rovnocennosti a obe testované skupiny - kontrolná aj experimentálna sa navzájom nelíšili. Po rozbore stredných hodnôt $\mathrm{z}$ tabul'ky 2, sme za experimentálne triedy zvolili triedy A1 vprvom a B2 vdruhom roku výskumu, a za kontrolné triedy B1 v prvom a A2 v druhom roku výskumu.

\begin{tabular}{|c|c|c|c|c|c|c|c|c|c|}
\hline \multirow{2}{*}{$\begin{array}{c}\text { 1. rok } \\
\text { výskumu }\end{array}$} & \multicolumn{4}{|c|}{\begin{tabular}{|l|l} 
1. vstupný test & 2. vstupný test
\end{tabular}} & \multirow{2}{*}{$\begin{array}{c}\text { 2. rok } \\
\text { výskumu }\end{array}$} & \multicolumn{2}{|c|}{ 1. vstupný test } & \multicolumn{2}{|c|}{ 2. vstupný test } \\
\hline & $\mathrm{A} 1$ & B1 & $\mathrm{A} 1$ & $\mathrm{~B} 1$ & & $\mathrm{~A} 2$ & B2 & A2 & B2 \\
\hline Str. hodnota & 39,7 & 53,4 & 37,6 & 45,2 & Str. hodnota & 48,7 & 45,6 & $\overline{39,6}$ & 34,1 \\
\hline Rozptyl & $\overline{778,4}$ & 656,4 & 692,1 & 607,9 & Rozptyl & 732,7 & 804,9 & 923,4 & $\overline{1004,1}$ \\
\hline t stat & $-1,886$ & & $-1,102$ & & t stat & 0,435 & & 0,698 & \\
\hline$P(T<=t)(2)$ & 0,065 & & 0,275 & & $\mathrm{P}(\mathrm{T}<=\mathrm{t})(2)$ & 0,664 & & 0,488 & \\
\hline t krit (2) & 2,008 & & 2,008 & & $\mathrm{t}$ krit (2) & 2,001 & & 2,001 & \\
\hline
\end{tabular}

Tabul'ka 2: Výsledky štatistických parametrov vstupných testov v 1. a 2. roku výskumu.

\section{Priebežné testy}

Priebežných testov sa zúčastnili všetky triedy zaradené do pedagogického experimentu. Triedy A1, B2 predstavovali experimentálnu triedu (ozn. E) a triedy B1, A2 kontrolnú triedu (ozn. K). Prostredníctvom priebežných didaktických testov sme overovali platnost' nasledujúcej $H_{0}$ nulovej hypotézy $H_{0}$.

$H_{0}$ : Skóre priebežných vedomostných testov u experimentálnych a kontrolných tried sa štatisticky významne nelíši.

Oproti testovanej nulovej hypotéze $H_{0}$ sme položili alternatívnu hypotézu $H_{1}$.

$H_{1}$ : Dosiahnuté skóre v priebežných didaktických testoch je v experimentálnych a kontrolných triedach štatisticky významne rozdielne.

$\mathrm{Na}$ overovanie platnosti nulovej hypotézy sme použili dvojvýberový t-test.

Po každom experimentálnom dvojhodinovom cvičení nasledoval didaktický test. Výsledky testov sme podrobili štatistickej analýze a výsledky štatistických parametrov sme zapísali do tabuliek č. 3 až č. 7. Spolu sme realizovali pät' priebežných didaktických testov.

1. priebežný test pozostával z piatich úloh s rôznymi váhami významu. Test bol zameraný na fyzikálne vlastnosti diódy a tranzistora, vplyv teploty na zmenu ich vlastností a ich možné aplikácie v obvodoch.

\begin{tabular}{|lcc|}
\hline $\begin{array}{l}\text { Dvojvýberový t-test s nerovnost'ou } \\
\text { rozptylov 1. priebežného testu }\end{array}$ \\
\hline \multicolumn{1}{|c|}{ trieda } & $E$ & $K$ \\
\hline Str. hodnota & 54,69 & 40,37 \\
Rozptyl & 480,5 & 580,2 \\
Pozorovanie & 56 & 61 \\
Hyp. rozdiel str. hodnôt & 0,000 & \\
Rozdiel & 115,0 \\
$t$ stat & 3,366 \\
$\mathrm{P}(\mathrm{T}<=\mathrm{t})(1)$ & 0,001 \\
$\mathrm{t}$ krit $(1)$ & 1,658 \\
$\mathrm{P}(\mathrm{T}<=\mathrm{t})(2)$ & 0,001 \\
$\mathrm{t}$ krit $(2)$ & 1,981 \\
\hline
\end{tabular}

Tabul'ka 3: Výsledky testovania nezávislosti EXS a KS v 1. priebežnom teste

Ked’že $\quad t_{\text {stat }}=3,37>1,98($ Tab. 11), nulovú hypotézu $H_{0}$ zamietame na hladine významnosti $\alpha=0,05$. Tento záver potvrdzuje aj vypočítaná hodnota pravdepodobnosti $\quad \mathrm{P}=0,001$. To znamená, že medzi výsledkami, ktoré dosiahli žiaci $\mathrm{V}$ prvom priebežnom teste $\mathrm{z}$ kontrolnej a experimentálnej triedy je štatisticky významný rozdiel $\mathrm{v}$ prospech experimentálnej triedy.

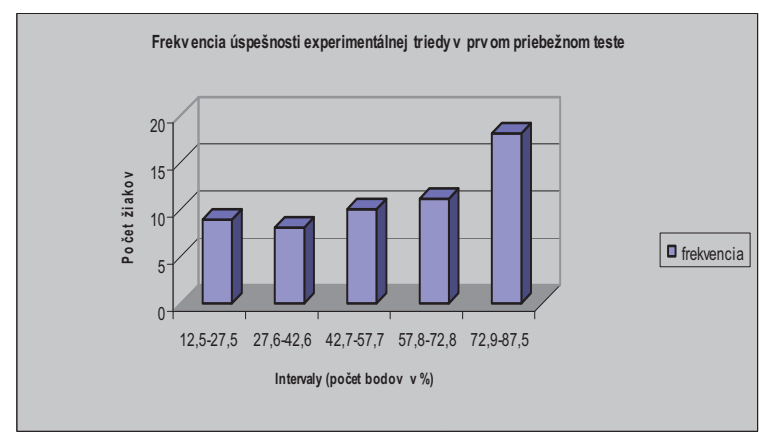

Obr. 1: Graf úspešnosti experimentálnej triedy. 


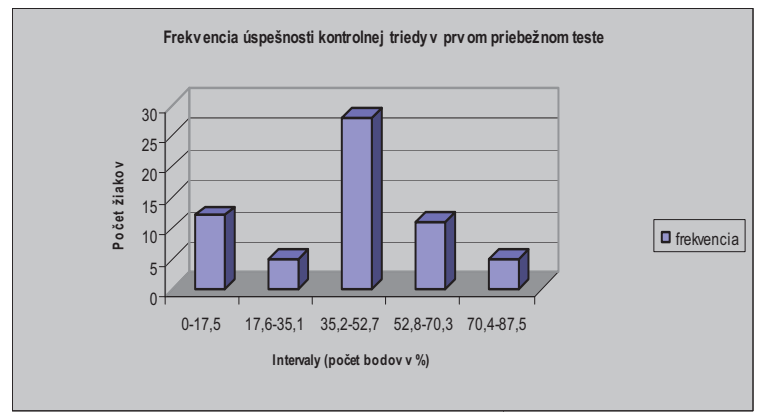

Obr. 2: Graf úspešnosti kontrolnej triedy.

2. priebežný test bol skórovaný okrem štvrtej úlohy binárne s rôznymi váhami významu.

Test bol zameraný na príklady stabilizácie pracovného bodu bipolárneho tranzistora, význam odporov $R_{\mathrm{E}} \quad \mathrm{a} \quad \mathrm{C}_{\mathrm{E}} \quad \mathrm{v}$ zapojení jednostupňového zosilňovača a výpočet prvkov mostíkovej stabilizácie pracovného bodu tranzistora v zapojení so spoločným emitorom.

\begin{tabular}{|lcc|}
\hline \multicolumn{3}{|l|}{$\begin{array}{l}\text { Dvojvýberový t-test s nerovnost'ou } \\
\text { rozptylov 2. priebežného testu }\end{array}$} \\
\hline \multicolumn{1}{|c|}{ trieda } & $E$ & $K$ \\
\hline Str. hodnota & 60,71 & 48,67 \\
Rozptyl & 865,7 & 1164,2 \\
Pozorovanie & 56 & 61 \\
Hyp. rozdiel str. hodnôt & 0 & \\
Rozdiel & 115 & \\
t stat & 2,050 \\
$\mathrm{P}(\mathrm{T}<=\mathrm{t})(1)$ & 0,021 & \\
$\mathrm{t} \mathrm{krit}(1)$ & 1,658 \\
$\mathrm{P}(\mathrm{T}<=\mathrm{t})(2)$ & 0,043 \\
$\mathrm{t} \mathrm{krit}(2)$ & 1,981 \\
\hline
\end{tabular}

Tabul'ka 4: Výsledky testovania nezávislosti EXS a KS v 2. priebežnom teste.

Ked', že $t_{\text {stat }}=2,05>1,98$, nulovú hypotézu $H_{0}$ zamietame na hladine významnosti $\alpha=0,05$ a tento záver potvrdzuje aj hodnota pravdepodobnosti, ktorá je $0,04<0,05$ pre ktorú prijímame alternatívnu hypotézu. Medzi výsledkami, ktoré dosiahli žiaci v priebežnom teste $\mathrm{z}$ kontrolnej a experimentálnej triedy je štatisticky významný rozdiel v prospech experimentálnej triedy.

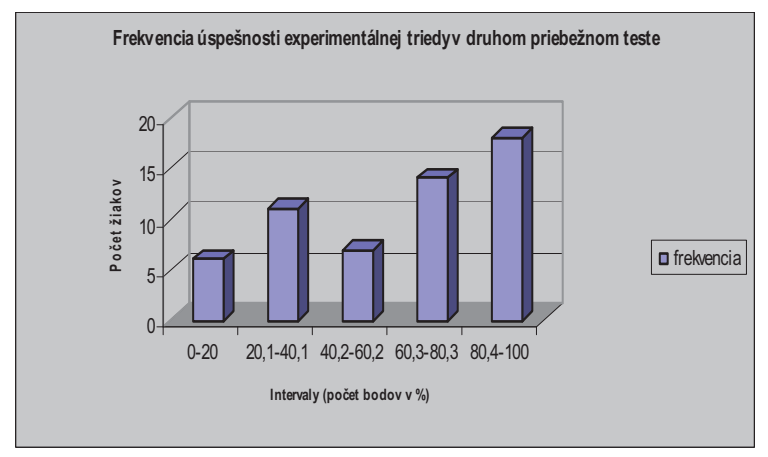

Obr. 3: Graf úspešnosti experimentálnej triedy.

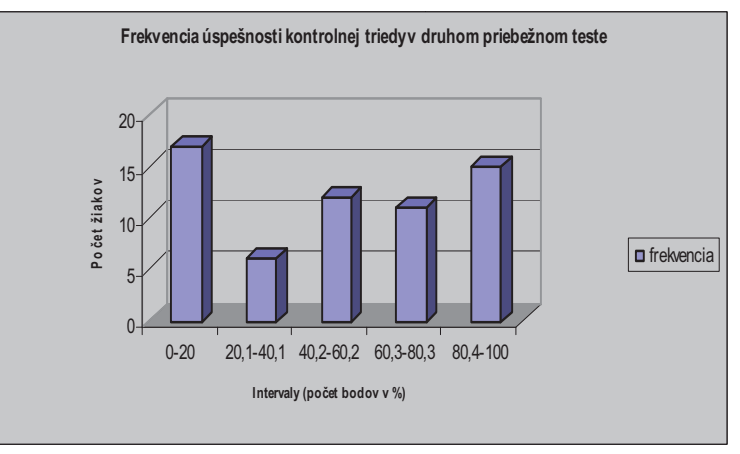

Obr. 4: Graf úspešnosti kontrolnej triedy.

V poradí 3. priebežný test pozostával zo siedmich úloh s rôznou váhou významu zameraných na fyzikálne vlastnosti viacvrstvových polovodičových súčiastok, výstupné priebehy usmerňovačov a návrh parametrického stabilizátora napätia.

\begin{tabular}{|c|c|c|}
\hline \multicolumn{3}{|c|}{$\begin{array}{l}\text { Dvojvýberový t-test s nerovnostou } \\
\text { rozptylov 3. priebežného testu }\end{array}$} \\
\hline trieda & $E$ & $K$ \\
\hline Str. hodnota & 70,46 & 57,45 \\
\hline Rozptyl & 504,0 & 677,7 \\
\hline Pozorovanie & 56 & 61 \\
\hline Hyp. rozdíl str. hodnôt & 0 & \\
\hline Rozdiel & 115 & \\
\hline t stat & 2,903 & \\
\hline$P(T<=t)(1)$ & 0,002 & \\
\hline t krit (1) & 1,658 & \\
\hline $\mathrm{P}(\mathrm{T}<=\mathrm{t})(2)$ & 0,004 & \\
\hline t krit (2) & 1,981 & \\
\hline
\end{tabular}

Tabul'ka 5: Výsledky testovania nezávislosti EXS a KS v 3. priebežnom teste.

Z tabul'ky 5 vidíme, že $\mathrm{t}_{\text {stat }}=2,90>1,98$, nulovú hypotézu $H_{0}$ zamietame na hladine významnosti $\alpha=0,05$ a tento záver potvrdzuje aj hodnota pravdepodobnosti, ktorá je $0,004<0,05$ pre ktorú prijímame alternatívnu hypotézu. Medzi výsledkami, ktoré dosiahli žiaci $\mathrm{v}$ priebežnom teste $\mathrm{z}$ kontrolnej a experimentálnej triedy je štatisticky významný rozdiel $\mathrm{v}$ prospech experimentálnej triedy.

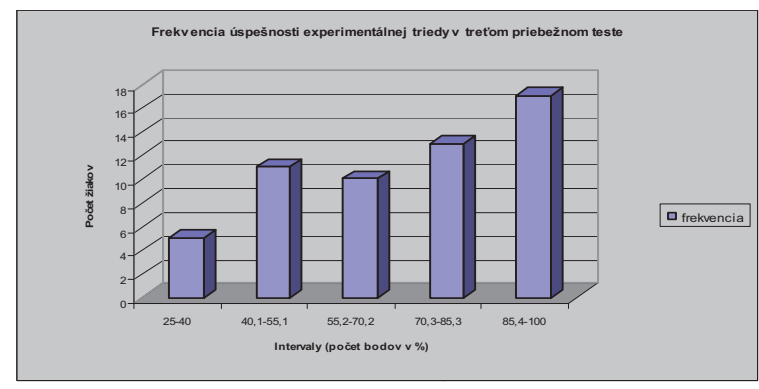

Obr. 5: Graf úspešnosti experimentálnej triedy. 


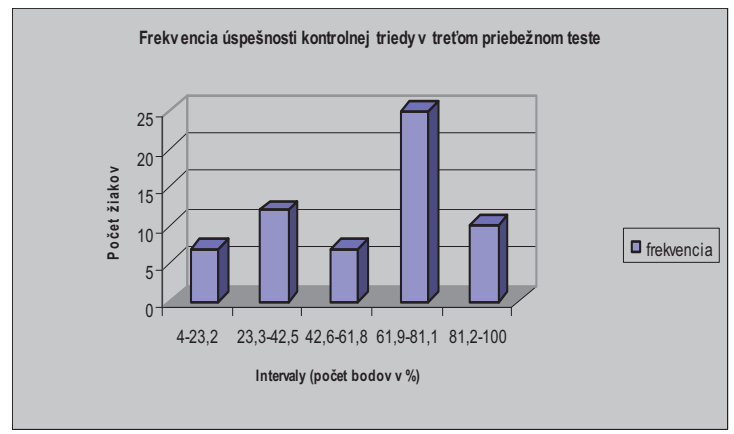

Obr. 6: Graf úspešnosti kontrolnej triedy.

4. priebežný test pozostával zo šiestich úloh s rôznou váhou významu, zameraných na vlastnosti a návrh zosilňovačov $(\mathrm{AFCH}$, zapojenie a princíp činnosti, výstupné priebehy jednotlivých tried zosilňovačov).

\begin{tabular}{|c|c|c|}
\hline \multicolumn{3}{|c|}{$\begin{array}{l}\text { Dvojvýberový t-test s nerovnostou } \\
\text { rozptylov 4. priebežného testu }\end{array}$} \\
\hline trieda & $E$ & $K$ \\
\hline Str. hodnota & 55,36 & 36,43 \\
\hline Rozptyl & 491,5 & 593,1 \\
\hline Pozorovanie & 56 & 61 \\
\hline Hyp. rozdiel str. hodnôt & 0 & \\
\hline Rozdiel & 115 & \\
\hline t stat & 4,400 & \\
\hline $\mathrm{P}(\mathrm{T}<=\mathrm{t})(1)$ & 0,00001 & \\
\hline t krit (1) & 1,658 & \\
\hline$P(T<=t)(2)$ & 0,00002 & \\
\hline t krit (2) & 1,981 & \\
\hline
\end{tabular}

Tabul'ka 6: Výsledky testovania nezávislosti EXS a KS v 4. priebežnom teste.

Z tabul'ky 6 vidno, že $t_{\text {stat }}=4,4>1,98$ nulovú hypotézu $H_{0}$ zamietame na hladine významnosti $\alpha=0,05$ a tento záver potvrdzuje aj hodnota pravdepodobnosti, ktorá je 0,00002 . To znamená, že medzi výsledkami, ktoré dosiahli žiaci v priebežnom teste z kontrolnej a experimentálnej triedy je štatisticky významný $\underline{\text { rozdiel }} \mathrm{v}$ prospech experimentálnej triedy.

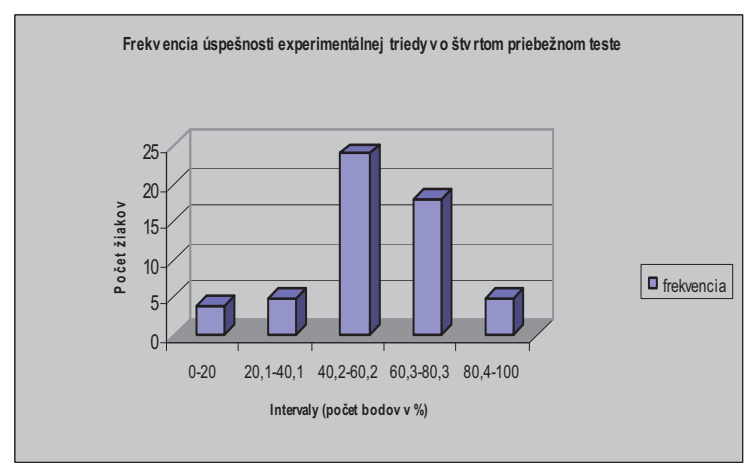

Obr. 7: Graf úspešnosti experimentálnej triedy

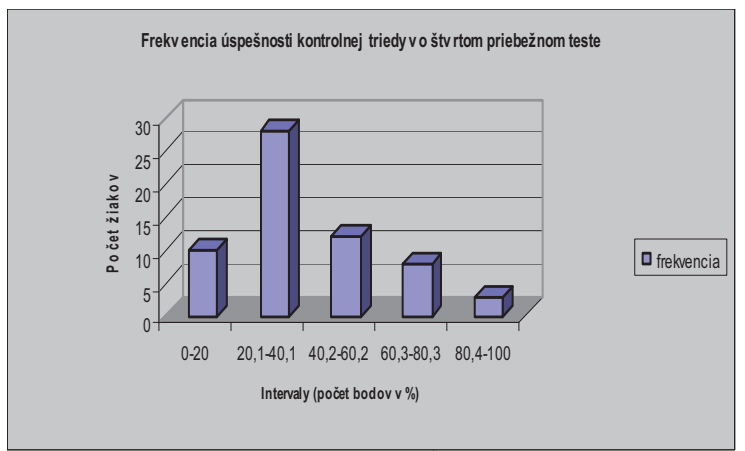

Obr. 8: Graf úspešnosti kontrolnej triedy.

5. priebežný test pozostával z piatich úloh s rôznou váhou významu a bol zameraný na klopné obvody, čas kyvu, časové priebehy, schémy zapojenia a výpočet obvodových prvkov astabilného preklápacieho obvodu.

\begin{tabular}{|c|c|c|}
\hline \multicolumn{3}{|c|}{$\begin{array}{l}\text { Dvojvýberový t-test s nerovnostou } \\
\text { rozptylov 5. priebežného testu }\end{array}$} \\
\hline trieda & $E$ & $K$ \\
\hline Str. hodnota & 65,58 & 55,74 \\
\hline Rozptyl & 511,1 & 693,4 \\
\hline Pozorovanie & 56 & 61 \\
\hline Hyp. rozdiel str. hodnôt & 0 & \\
\hline Rozdiel & 115 & \\
\hline t stat & 2,173 & \\
\hline $\mathrm{P}(\mathrm{T}<=\mathrm{t})(1)$ & 0,016 & \\
\hline t krit (1) & 1,658 & \\
\hline$P(T<=t)(2)$ & 0,032 & \\
\hline t krit (2) & 1,981 & \\
\hline
\end{tabular}

Tabul'ka 7: Výsledky testovania nezávislosti EXS a KS v5. priebežnom teste.

Z tabulky 7 vidno, že $\mathrm{t}_{\text {stat }}=2,173>1,98$, nulovú hypotézu $H_{0}$ zamietame na hladine významnosti $\alpha=0,05$ a tento záver potvrdzuje aj hodnota pravdepodobnosti, ktorá je 0,032 . To znamená, že medzi výsledkami, ktoré dosiahli žiaci $\mathrm{V}$ priebežnom teste $\mathrm{z}$ kontrolnej a experimentálnej triedy je štatisticky významný rozdiel $\mathrm{v}$ prospech experimentálnej triedy.

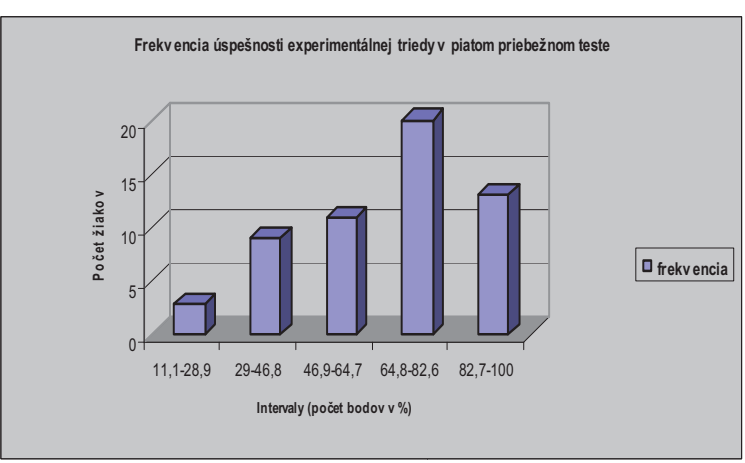

Obr. 9: Graf úspešnosti experimentálnej triedy. 
Frekvencia úspešnosti kontrolnej triedyv piatom priebežnom teste

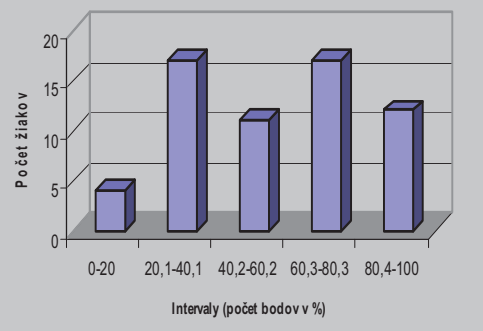

$\square$ frekvencia

Obr. 10: Graf úspešnosti kontrolnej triedy.

\section{Výstupný test}

Výstupný test pozostával z ôsmich čiastkových úloh a bol zameraný na trvalost' vedomostí. Obsah bol zostavený zo základných pojmov sledovanej oblasti učiva. Jeho realizácia prebehla naraz vo všetkých skupinách experimentálnej, ale aj referenčnej triedy. Výstupný test pozostával z dvoch častí: z časti zameranej na zapamätanie a časti zameranej na porozumenie učiva. Za prvé štyri čiastkové úlohy bolo možné dosiahnut' skóre po 2 body. Piata a šiesta čiastková úloha bola skórovaná binárne, ale za siedmu čiastkovú úlohu bolo možné dosiahnut' tri body, dôvodom bola požiadavka výpisu troch jednoduchých rovníc. Výstupným didaktickým testom sme overovali platnost' nulovej hypotézy $H_{0}$.

$H_{0}$ : Skóre výstupných vedomostných testov oboch tried sa štatisticky významne nelíši.

Oproti testovanej nulovej hypotéze $H_{0}$ sme položili alternatívnu hypotézu $H_{1}$.

$H_{1}$ : Dosiahnuté skóre vo výstupnom didaktickom teste je u oboch testovaných tried štatisticky významne rozdielne.

\begin{tabular}{|c|c|c|}
\hline \multicolumn{3}{|c|}{$\begin{array}{l}\text { Dvojvýberový t-test s nerovnost'ou } \\
\text { rozptylov výstupného testu }\end{array}$} \\
\hline trieda & $E$ & $K$ \\
\hline Str. hodnota & 62,1 & 45,8 \\
\hline Rozptyl & 195,82 & 386,36 \\
\hline Pozorovanie & 56 & 61 \\
\hline Hyp. rozdiel str. hodnôt & 0 & \\
\hline Rozdiel & 108 & \\
\hline t stat & 5,18 & \\
\hline$P(T<=t)(1)$ & 0,00000051 & \\
\hline t krit (1) & 1,659085144 & \\
\hline$P(T<=t)(2)$ & 0,00000102 & \\
\hline t krit (2) & 1,982 & \\
\hline
\end{tabular}

Tabul'ka 8: Výsledky testovania nezávislosti EXS a KS vo vstupnom teste.
Pre výstupný test (Tab. 19) platí: ked', že $\mathrm{t}_{\text {stat }}$ $=5,18>1,98$, a preto nulovú hypotézu $H_{0}$ zamietame na hladine významnosti $\alpha=0,05$. Tento záver potvrdzuje aj hodnota pravdepodobnosti, ktorá je $1,02 \times 10^{-6}$. To znamená, že medzi výsledkami, ktoré dosiahli žiaci vo výstupnom teste $\mathrm{z}$ kontrolnej a experimentálnej triedy je štatisticky významný rozdiel. Inými slovami metóda, ktorá bola použitá $\mathrm{v}$ experimentálnej triede bola účinná, lebo žiaci v experimentálnej triede dosiahli v oblasti trvácnosti vedomostí štatisticky významne lepšie výsledky.

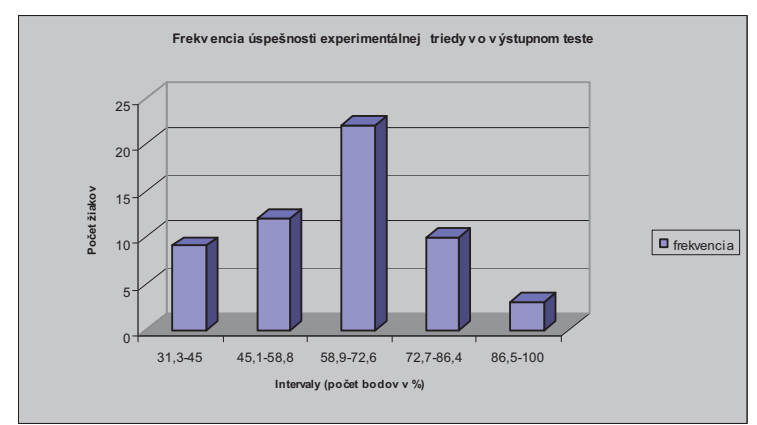

Obr. 11: Graf úspešnosti experimentálnej triedy.

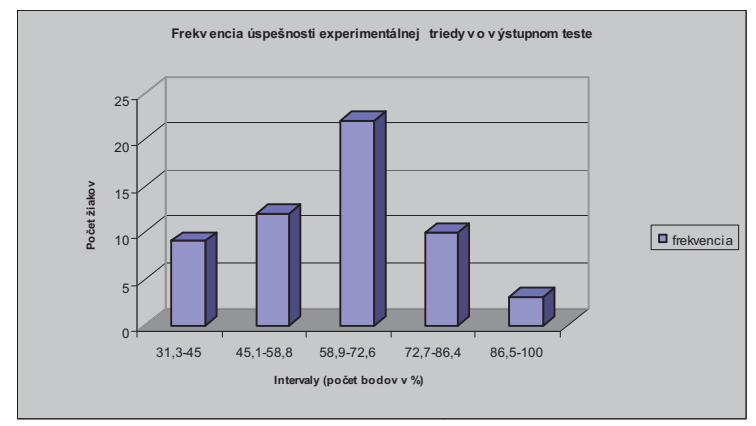

Obr. 12: Graf úspešnosti kontrolnej triedy.

\section{Interpretácia výsledkov výskumu}

Použitím Cochranov - Coxonovho testu pre analýzu priebežných testov sa z výsledku didaktických testov preukázalo potvrdenie platnosti hypotézy H(1): Dosiahnuté skóre $\mathrm{v}$ priebežných didaktických testoch je medzi experimentálnymi a kontrolnými triedami štatisticky významne rozdielne .

Inými slovami, môžeme konštatovat', že žiaci využívajúci matematické modelovanie vo forme simulačného programu implementovaného do výučby odborných predmetov sú lepšie motivovaní pri štúdiu daných predmetov, čím dosiahnu pozitívnejšie výsledky pri hodnoteni ako žiaci kontrolnej triedy vyučovaní tradične.

Štatistická analýza výstupného testu prostredníctvom Cochranov - Coxonovho testu 
umožnila zamietnut' nulovú hypotézu $H_{0}$ a tým potvrdit' platnost' hypotézy H(2): Žiaci začlenení do programu vyučovacích hodín so zaradeným simulačným programom mali trvácnejšie vedomosti $\mathrm{z}$ predmetu ako žiaci vyučovaní tradične.

Výsledky vstupných a výst. testu sme vzájomne neporovnávali pre odlišnost' obsahu ich úloh.

\section{Zhrnutie výsledkov výskumu a prínos pre pedagogickú prax}

$\mathrm{Na}$ základe predloženej výskumnej správy možno konštatovat', že žiaci zaradení do rozšíreného vyučovania s podporou simulačného programu MicroCap dosiahli vyššie skóre pri preverovaní vedomostí v priebežnom hodnotení a zároveň dosiahli trvácnejšie vedomosti potvrdené vo výstupnom teste. Sme presvedčení, že simulačný program MicroCap môže na stredných odborných školách elektrotechnického zamerania napomôct' oživit' tradičný spôsob vyučovania elektroniky prostredníctvom moderných technológií na báze IKT. Napriek tomu samotné využívanie simulačného softvéru neprinesie u žiakov okamžité zlepšenie výsledkov. Iba náležitá príprava žiaka na vyučovaciu hodinou a logická postupnost' obsahu učiva odovzdávaného učitel’om, doplnená o počítačové modelovanie, môže napomôct' zvýšeniu motivácie žiakov. U nepripravených žiakov môže dochádzat' $\mathrm{k}$ tendencii riešit' zadané úlohy metódou pokusu a omylu, ktorá je vo vzdelávacom prostredí neprípustná. MicroCap prípadne iný simulačný program vo výučbe nesmie byt' $\mathrm{v}$ žiadnom prípade používaný ako zdroj náhodných čísel, ale iba ako prostriedok overenia už vopred známych výsledkov získaných výpočtom.

Podl'a našich poznatkov by výsledky nášho výskumu mohli byt' prínosom z nasledujúcich dôvodov:

- nový prvok na oživenie tradičného vyučovania

- rozvíjajú sa kompetencie žiaka voblasti najmodernejších technológií pre návrh elektronických obvodov

- klasické precvičovanie príkladov sa obohatí o praktickú skúsenost' bez nákladného a zložitého laboratórneho vybavenia

- okamžitá spätná väzba v podobe nameraných (aj zobrazených) výsledkov pri simulácii po predchádzajúcom manuálnom výpočte obvodu možný d'alší rozvoj v rámci vysokoškolského štúdia

technická podpora v budúcom zamestnaní pri odstraňovaní porúch a riešení technických problémov

- technická podpora pre študentov elektrotechnických škôl v celoživotnom vzdelávaní $\mathrm{v}$ rámci svojej profesie

\section{Záver}

Prezentované výsledky výskumu predstavujú štvorročné úsilie hl'adania účinnejších metód na zefektívnenie tradičného vyučovania na strednej odbornej škole aplikáciou informačných a komunikačných technológií. Naše výsledky výskumu majú slúžit širokej odbornej verejnosti, prípadne ako podnet $\mathrm{k}$ d’alšiemu experimentovaniu.

\section{Použitá literatúra:}

(1) ARPÁŠ, J. - SOTÁK, V. 2007. Počítačové modelovanie vo výučbe elektroniky zamerané na zvýšenie motivácie žiakov SOŠ I. Technológia vzdelávania, roč. XV, 2007, č. 10, s. 13-16.

(2) ARPÁS̆S, J. - SOTÁK, V. 2008. Počítačové modelovanie vo výučbe elektroniky zamerané na zvýšenie motivácie žiakov SOŠ II. Technológia vzdelávania, roč. XVI, 2008, č.2, Príloha Slovenský učitel', s. 2-5.

(3) LÁNÍČEK, R. 2002. Simulační programy pro elektroniku. Praha, BEN - technická literatura, 2002, ISBN 80-7300-051-2.

(4) TIRPÁKOVÁ, A. 2007. Základy štatistiky. UKF Nitra. ISBN 978-80-8094-220-5.

(5) TUREK, I. 1995. Kapitoly z didaktiky Didaktické testy. Bratislava. MC, 1995. ISBN 80-88796-99-7.

(6) TUREK, I. 1996. Učitel' a pedagogický výskum. Bratislava. MC, 1996. ISBN 80-7164173-1.

(7) TUREK, I. 2008. Didaktika. Bratislava. Iura Edition, 2008. ISBN 978-80-8078-198-9.

\section{Ing. Július Arpáš}

SPŠ Nitra, Ul. Fraňa Král'a, 94901 Nitra e-mail: arpasj@post.sk

Doc. Ing. Vladimír Soták, CSc.

KTIT, PF UKF v Nitre, Drážovská 4, 94974 Nitra, e-mail: vsotak@ukf.sk

Doc. RNDr. Anna Tirpáková, CSc.

Katedra matematiky, FPV UKF,

Tr. A. Hlinku 1, 94901 Nitra

e-mail: atirpakova@ukf.sk 